\title{
Changes in Udder Surface Temperature and Milk Quality Characteristics in Cows during the Hot Season
}

\author{
Hüseyin Erdem ${ }^{1, a, *}$, İbrahim Cihangir Okuyucu ${ }^{1 \mathrm{~b}}$ \\ ${ }^{1}$ Department of Animal Science, Faculty of Agriculture, Ondokuz Mayls University, 55139 Samsun, Turkey \\ *Corresponding author

A R T I C LE I N F O A B S T R A C T \\ Research Article \\ The aim of this study was to determine the relationships of udder surface temperature (UST) with \\ milk components, and somatic cell count (SCC) in dairy cows during the hot season. The study was \\ carried out with 115 lactating dairy cows (Holstein, Simmental, and Holstein $\times$ Simmental) at a \\ private dairy farm in Samsun, Turkey, with monthly visits. The UST was measured from the udder \\ Received : 09/06/2021 \\ Accepted : 28/01/2022 \\ surface before cleaning and milking. At the same time, a portable cell counter and an automatic \\ milk analyzer were used to determine the components and the SCC of the raw milk. The UST values \\ of the cows changed significantly. Increased UST had an adverse effect on milk solids-non-fat \\ (SNF), protein, lactose, and density levels. LogSCC values of cow groups with UST $\leq 35.0^{\circ} \mathrm{C}, 35.1$ - \\ $36.0^{\circ} \mathrm{C},>36.0^{\circ} \mathrm{C}$ were found to be $4.475 \pm 0.0803,4.774 \pm 0.1244$, and $4.981 \pm 0.1491$ respectively. \\ The UST negatively correlated with SNF, protein, lactose, density, and freezing point, but positively \\ Keywords: \\ Udder surface temperature \\ correlated with $\operatorname{LogSCC}$. As a result, performing UST measurements before milking may be \\ Raw milk \\ beneficial to monitor udder health and to obtain high quality milk.
}

Milk components

Somatic cell count

Cow

hserdem@omu.edu.tr

(D) https://orcid.org/0000-0001-5273-3925

| b@ cihangir.okuyucu@omu.edu.tr

Dittps://orcid.org/0000-0002-2138-6577

(c) (1) (8) This work is licensed under Creative Commons Attribution 4.0 International License

\section{Introduction}

In recent years, intensification has rapidly increased in dairy farms (Simitzis et al.,2022). This increases the importance of udder health programs in dairy farms to obtain high quality and hygienic milk (Schukken et al., 2003; Zaninelli et al., 2018). It is well known that the udder health of cows is determined mostly by the conditions of their barn. In particular, the cleanliness of the cow is associated with clean alleys and bedding material, along with proper manure management (Köster et al., 2006; Sant'Anna and Paranhos da Costa, 2011). The cleanliness of the cow can not only affect udder health, but also indirectly the quality and quantity of milk produced (Schreiner and Ruegg, 2003; Ellis et al., 2007; Erdem and Okuyucu, 2019). In addition, milking location, fully operable milking machines, and adherence to milking rules are important environmental factors affecting udder health (Aytekin and Boztepe, 2014).

Mastitis is an important udder disease that causes physical, chemical, and bacteriological changes in milk and economic losses (Kul et al., 2006; Sharma et al., 2011; Yang et al., 2018). It is possible for cows raised in poor hygiene and unhealthy conditions to have mastitis. The somatic cell count (SCC) is widely used to detect cases of mastitis (Sharma et al., 2011; Rainard et al., 2018). The cow's defense mechanism against mastitis is SCC in the milk. The value of SCC in milk rises to very high levels as a response to infection in the udder. High SCC in milk indicates that the animals are unhealthy or the farm has poor hygiene standards. This situation increases the risk of contamination with pathogenic microorganisms and presence of antibiotic residues in raw milk (Schukken et al., 2003; Aytekin and Boztepe, 2014). If intra-mammary infections occur some physiological changes (in rectal temperature, heart, respiration rates, and udder surface temperature) will possibly be observed in the cows (Zaninelli et al., 2018). Researchers confirmed that the increase in the temperature of the affected portion of the udder is due to intra-mammary infection (Berry et al, 2003; Polat et al., 2010; Bortolami et al., 2015). Moreover, the udder surface temperature (UST) shows the status of tissue and blood circulation in the entire udder of the cow (Sathiyabarathi et al., 2016; Sathiyabarathi et al., 2018). 
Nowadays, the UST is widely determined by infrared thermography. This method is based on measuring the heat radiating from the skin depending on the circulation and metabolism. Since mastitis causes localized symptoms such as swelling, pain, and fever in subcutaneous tissues, these symptoms can be detected directly with this method (Hovinen et al., 2008). Many study results revealed have shown that UST values positively correlate with elevated SCC and the California Mastitis Test (CMT) results (Colak et al., 2008; Sathiyabarathi et al., 2016; Sathiyabarathi et al., 2018). Considering that the UST is influenced by SCC, it may be a better method for early detection of intramammary infections in order to obtain high-quality milk and reduce milk production losses in dairy herds. Although many studies have focused on the relationship between UST and SCC in dairy herds (Berry et al., 2003: Colak et al., 2008; Polat et al., 2010; Bortolami et al., 2015). The number of studies on the association of UST with milk components and SCC is still limited. Our primary objective was to investigate the effects of UST on SCC and milk components in dairy cows.

\section{Materials and Methods}

The research was conducted with 115 lactating multiparous cows (Holstein $(n=32)$, Simmental $(n=46)$, and Holstein $\mathrm{x}$ Simmental $(\mathrm{n}=37))$ at a private dairy farm in Samsun, Turkey. This farm is located at $40^{\circ} 50^{\prime}-41^{\circ}$ $51^{\prime} \mathrm{N}, 37^{\circ} 08^{\prime}-34^{\circ} 25^{\prime} \mathrm{E}$ and situated in the Black Sea Region of Turkey. The farm was visited once a month between June and September. The cows used in the study were housed in closed barns with a concrete floor. They were milked twice daily by a portable milking system during the study period.

The UST was measured at a distance of $5 \mathrm{~cm}$ from the udder by a calibrated non-contact infrared thermometer (plusMED pm-8806H). Also, the measurements were made while the cows were standing, prior to udder cleaning and milking. The UST was taken separately for each quarter of the udder. After determining the UST, the average value was obtained by taking the arithmetic mean of all quarters of the udder of each cow. The average UST was classified into one of three groups $\left(1\right.$. Group: $\leq 35.0^{\circ} \mathrm{C}$; 2. Group: $35.1-36.0^{\circ} \mathrm{C} ; 3$. Group: $\left.>36.0^{\circ} \mathrm{C}\right)$.

Milk samples were collected at the morning milking. From each cow, the samples (about $50 \mathrm{ml}$ ) were homogeneously collected from milk buckets after completing milking process. The samples were transferred to the laboratory within two hours on ice for analysis of SCC and milk components. To measure these, the samples were heated up to the body temperature of cows $\left(37-38^{\circ} \mathrm{C}\right)$ in a hot water bath. Then fat, SNF, protein, lactose, density, freezing point, and the mineral content of the milk were analyzed by an automatic milk analyzer (Lactostar, FunkeGerber, Berlin, Germany). Additionally, a portable cell counter (DeLaval, Tumba, Sweden) was used to determine the milk SCC. All SCC values were transferred to $\log 10$ base (LogSCC) to ensure homogeneity and uniformity of variance.

In this study, the three genotype groups (1: Holstein, 2:Simmental and 3: $\mathrm{H} \times \mathrm{S}$ crossbred) and four test month groups (1:June, 2:July, 3:August, and 4:September) were used.
To evaluate the effect of UST on milk composition and $\operatorname{LogSCC}$, the following model was used:

$$
Y_{i j}=\mu+a_{i}+e_{i j}
$$

where $Y_{i j}$ is the observation value (fat, SNF, protein, lactose, density, freezing point, mineral, and LogSCC), $\mu$ is the overall mean, $a_{i}$ is the effect of UST ( $\mathrm{i}=1,2$ and 3 ), $e_{i j}$ is a random error.

In addition, the following model was used to evaluate the effects of genotype and test month on UST:

$$
Y_{i j k}=\mu+b_{i}+c_{j}+e_{i j k}
$$

where $Y_{i j k}$ is the observation value (UST), $\mu$ is the overall mean, $b_{i}$ is the effect of genotype ( $\mathrm{j}=1,2$ and 3$), c_{j}$ is the effect of test month $(\mathrm{j}=1,2,3$ and 4$)$, and $e_{i j k}$ is a random error.

Duncan's multiple comparison test was used to compare the factors affecting the examined properties. In addition, the relationship of UST with SCC and milk components was analyzed using the Pearson correlation test. SPSS 17.0 was used for the all statistical analyses.

\section{Results and Discussion}

As shown in Table 1, the average UST value was found to be $35.39 \pm 0.08^{\circ} \mathrm{C}$. The effects of the three different genotypes on UST were determined to be insignificant. However, the results revealed that effect of test month was significant $(\mathrm{P}<0.01)$. The highest UST was found in June and August $\left(35.76 \pm 0.10^{\circ} \mathrm{C}\right.$ and $35.66 \pm 0.14^{\circ} \mathrm{C}$, respectively) as compared to September $\left(34.83 \pm 0.16^{\circ} \mathrm{C}\right)$. There was no significant difference between the average of July and other months. In an earlier study, Berry et al. (2003) found the mean preexercise UST value $\left(33.42^{\circ} \mathrm{C}\right)$ was lower than the postexercise UST value $\left(34.46^{\circ} \mathrm{C}\right)$ in multiparous Holstein Friesian cows. Poikalainen et al. (2012) reported that premilking the surface temperatures of hind right and left udder quarters were $32.4^{\circ} \mathrm{C}$. In another study (Yang, et al., 2018), the UST values before and after milking were determined to be $35.79^{\circ} \mathrm{C}$ and $37.10^{\circ} \mathrm{C}$ for the right hind udder and $35.87^{\circ} \mathrm{C}$ and $37.16^{\circ} \mathrm{C}$ for the left hind udder, respectively. An average UST value of $34.04^{\circ} \mathrm{C}$ for Holstein $(\mathrm{n}=45)$ and Brown Swiss $(n=49)$ cows was also determined by Colak et al. (2008). In this study, the UST values were higher compared to many studies (Berry et al., 2003; Colak et al., 2008; Porcionato et al., 2009; Poikalainen et al., 2012). However, the UST value obtained in this study was lower than the UST values of cows with healthy $\left(37.1 \pm 0.08^{\circ} \mathrm{C}\right)$, subclinical $\left(37.9 \pm 0.09^{\circ} \mathrm{C}\right)$, and clinical mastitis $\left(38.2 \pm 0.10^{\circ} \mathrm{C}\right)$ reported by Sathiyabarathi et al. (2018).

SNF $(\mathrm{P}<0.05)$, protein, and lactose $(\mathrm{P}<0.01)$ were affected by changes in UST, but fat was not (Table 2 ). The percentage of milk SNF, protein and lactose decreased with elevated UST. Besides, the highest SNF, protein, and lactose percentages were measured in the $\leq 35.0^{\circ} \mathrm{C}$ group, but the lowest in $>36.0^{\circ} \mathrm{C}$ group.

It was determined that milk density and $\operatorname{LogSCC}$ were affected $(\mathrm{P}<0.01)$ by UST (Table 2$)$. A dramatic increase in UST values was found in conjunction with elevated SCC. Also, the LogSCC was higher in the third UST group, as compared to the first group (4.475 \pm 0.0803$)$. 
Table 1. Effect of genotype and test month on UST of cows (mean \pm SE)

\begin{tabular}{|c|c|c|}
\hline \multirow{2}{*}{ Genotype } & \multicolumn{2}{|c|}{ UST $\left({ }^{\circ} \mathrm{C}\right)$} \\
\hline & $\mathrm{n}$ & mean \pm SE \\
\hline Holstein & 32 & $35.48 \pm 0.17$ \\
\hline Simmental & 46 & $35.39 \pm 0.12$ \\
\hline Crosbred & 37 & $35.31 \pm 0.12$ \\
\hline Month & $\mathrm{n}$ & $* *$ \\
\hline June & 26 & $35.76 \pm 0.10^{b}$ \\
\hline July & 32 & $35.33 \pm 0.16^{\mathrm{ab}}$ \\
\hline August & 29 & $35.66 \pm 0.14^{\mathrm{b}}$ \\
\hline September & 28 & $34.83 \pm 0.16^{\mathrm{a}}$ \\
\hline Overall & 115 & $35.39 \pm 0.08$ \\
\hline
\end{tabular}

** $\mathrm{P}<0.01$; a,b: Means within columns with different superscripts differ; UST: Udder Surface Temperature

Table 2. Effect of UST on milk components and $\operatorname{logSCC}($ mean $\pm \mathrm{SE})$

\begin{tabular}{|c|c|c|c|c|c|}
\hline \multicolumn{2}{|c|}{ UST Groups/n } & Fat $(\%)$ & SNF $(\%)$ & Protein $(\%)$ & Lactose $(\%)$ \\
\hline UST & $\mathrm{n}$ & & $*$ & $* *$ & $* *$ \\
\hline$\leq 35.0^{\circ} \mathrm{C}$ & 53 & $3.44 \pm 0.14$ & $8.47 \pm 0.06^{\mathrm{b}}$ & $3.11 \pm 0.03^{\mathrm{b}}$ & $4.31 \pm 0.05^{\mathrm{b}}$ \\
\hline $35.1-36.0^{\circ} \mathrm{C}$ & 33 & $3.45 \pm 0.21$ & $8.28 \pm 0.08^{\mathrm{ab}}$ & $2.99 \pm 0.04^{\mathrm{ab}}$ & $4.14 \pm 0.06^{\mathrm{ab}}$ \\
\hline$>36.0^{\circ} \mathrm{C}$ & 29 & $3.62 \pm 0.19$ & $8.10 \pm 0.17^{\mathrm{a}}$ & $2.91 \pm 0.07^{\mathrm{a}}$ & $4.02 \pm 0.10^{\mathrm{a}}$ \\
\hline \multicolumn{2}{|c|}{ UST Groups/n } & Density (mg/ml) & Freezing Point $\left({ }^{\circ} \mathrm{C}\right)$ & Mineral (\%) & LogSCC \\
\hline UST & $\mathrm{n}$ & $* *$ & & & $* *$ \\
\hline$\leq 35.0^{\circ} \mathrm{C}$ & 53 & $1.0273 \pm 0.0004^{\mathrm{b}}$ & $-0.485 \pm 0.0403$ & $0.877 \pm 0.0110$ & $4.475 \pm 0.0803^{\mathrm{a}}$ \\
\hline $35.1-36.0^{\circ} \mathrm{C}$ & 33 & $1.0255 \pm 0.0005^{\mathrm{ab}}$ & $-0.555 \pm 0.0037$ & $0.852 \pm 0.0129$ & $4.774 \pm 0.1244^{\mathrm{ab}}$ \\
\hline$>36.0^{\circ} \mathrm{C}$ & 29 & $1.0245 \pm 0.0006^{\mathrm{a}}$ & $-0.577 \pm 0.0086$ & $0.924 \pm 0.0392$ & $4.981 \pm 0.1491^{b}$ \\
\hline
\end{tabular}

In this study, the LogSCC of the cows in the third UST group was higher than those with $\leq 35.0^{\circ} \mathrm{C}$ and, the LogSCC tended to rise as the UST increased (Table 2). In contrast, Golzarian et al., (2017) reported no statistically significant difference between healthy udder tissue (UST $35.70^{\circ} \mathrm{C}$ ) and unhealthy udder tissue (UST $35.26^{\circ} \mathrm{C}$ ) values. In another study, Barth (2000) reported that the UST of the cows with high SCC were higher than those with low SCC. Similarly, Sathiyabarathi et al. (2016) emphasized that the UST values of the infected intramammary quarters were significantly higher than those without infection. Also, Sathiyabarathi et al. (2018) reported that the UST value of cows without mastitis $\left(37.1 \pm 0.08^{\circ} \mathrm{C}\right)$ was lower than those with subclinical $\left(37.9 \pm 0.09^{\circ} \mathrm{C}\right)$ and clinical mastitis $\left(38.2 \pm 0.10^{\circ} \mathrm{C}\right)$. Similarly, Silva et al. (2019) reported that cows with subclinical $\left(33.2-34.64{ }^{\circ} \mathrm{C}\right)$ and clinical mastitis $(34.0$ $37.5^{\circ} \mathrm{C}$ ) had higher UST values than healthy ones. The researchers reported that the average UST of healthy cows ranged from $29.3 \pm 1.78{ }^{\circ} \mathrm{C}$ to $32.24 \pm 0.62{ }^{\circ} \mathrm{C}$. Colak et al. (2008) reported that the CMT score increased from 0 to +3 as the UST increased from 33.19 to $36.15^{\circ} \mathrm{C}$. In another investigation, the average UST values of cows with negative CMT scores, $+1,+2$, and +3 , were found to be $33.23,34.64,35.73$, and $36.27^{\circ} \mathrm{C}$ (Polat, et al., 2010). The results obtained in this study are consistent with the findings of many studies (Barth, 2000; Colak et al., 2008; Sathiyabarathi et al., 2016; Sathiyabarathi et al., 2018; Silva et al., 2019). The origin of elevated UST can be explained by an intra-mammary infection (Zaninelli et al., 2018) because when an udder infection occurs, the body's defense mechanism causes an increase in udder temperature. In a review, Aytekin and Boztepe (2014) emphasized that elevated SCC in milk causes damage to the milk-secreting cells in the mammary glands.
As seen in Table 3, positive or negative correlation coefficients were determined between UST and milk quality parameters or LogSCC. The highest correlation coefficient was determined between UST and density $(r=-0.45)$. The UST of cows negatively influenced SNF, protein, and lactose percentage of milk except for fat and mineral content. This study disagrees with the results of Porcionato et al. (2009), who obtained insignificant relationship between SCC and UST. However, this relation was found to be 0.73 and 0.93 in similar studies by Polat et al., (2010) and Sathiyabarathi et al., (2016) respectively. The differences in the research results may be caused by the herd management or breed of the cows. As expected, these results showed that an increase in UST negatively affected SNF, protein, lactose and density in milk. It is thought that the increase in UST is due to the increase in SCC, and therefore elevation of SCC may adversely affect some milk components. In other words, high SCC has a remarkable effect on milk components and UST in dairy cows. Ayasan et al. (2011) reported that cows with high SCC had lower SNF, lactose, and density in milk than cows with low SCC. Also, Rekik et al. (2008) emphasized that an increase in SCC caused a decrease in milk fat and protein levels. Clear effects of SCC on some milk components have been reported previously (Rekik et al., 2008; Atasever and Erdem, 2008; Ayasan et al., 2011). Aytekin and Boztepe (2014) emphasized that high SCC causes the changes in milk enzymes and this may result in the disruption of milk protein and fat. In particular, they suggested that the increased level of plasmin due to the increase in SCC may negatively affect the level of casein. It is inevitable that this change in milk components will negatively affect the conversion of milk to products such as butter, cheese, and cream. For this reason, early detection of mastitis will be beneficial for breeders in terms of reducing economic losses and drops in the quality of dairy products. 
Table 3. Correlation coefficients of UST with milk components and LogSCC

\begin{tabular}{l|c}
\hline \multicolumn{1}{c|}{ Milk components and LogSCC } & UST \\
\hline Fat & 0.08 \\
SNF & $-0.30^{* *}$ \\
Protein & $-0.37^{* *}$ \\
Lactose & $-0.37^{* *}$ \\
Density & $-0.45^{* *}$ \\
Freezing Point & -0.20 \\
Mineral & 0.18 \\
LogSCC & $0.40^{* *}$ \\
** P<0.01
\end{tabular}

\section{Conclusions}

The rapid increase in intensification and the widespread use of cows with high milk production in dairy cattle herds has indirectly increased the environmental sensitivity of cattle. This particularly increases the risk of udder infections resulting in economic losses. Consequently, continuous monitoring of udder infections is an important part of successful herd management. Early detection of mastitis can minimize damage to udder tissues and reduce veterinary costs. Therefore, fast and high accuracy identification techniques for the early detection of mastitis in dairy herds should be developed and deployed extensively. The number of studies on continuous monitoring of udder health and establishing appropriate udder health programs has increased in recent years. In this study, the increase in skin surface temperature of the udder may indicate the risk of intra-mammary infection. This situation dramatically affects the LogSCC and some of the main components of milk. In summary, the increase of UST indicates adverse effects on udder health, and hence milk hygiene and quality. Determining the UST before each milking may be beneficial for maintaining udder health, obtaining high quality milk, and reducing milk production losses. To obtain these benefits, more studies are needed of the reliability of UST measurements and for their practical use in dairy herds. For this purpose, the widespread use of body temperature-sensitive thermal cameras will increase success in early detection of mastitis. In addition, detailed studies should be conducted on environmental factors affecting UST.

\section{References}

Atasever S, Erdem H. 2008. Relationships between mastitis and electrical conductivity of raw milk in dairy cows. Journal of Faculty of Agriculture, OMU, 23(2):131-136.

Ayasan T, Hizlı H, Yazgan E, Kara U, Gok K. 2011. The effect of somatic cell count on milk urea nitrogen and milk composition. Journal of the Faculty of Veterinary Medicine, Kafkas University, 17(4): 659-662.

Aytekin I, Boztepe S. 2014. Somatic Cell Count, Importance and Effect Factors in Dairy Cattle. Turkish Journal of Agriculture - Food Science And Technology, 2(3): 112-121.

Barth K. 2000. Basic investigations to evaluate a highly sensitive infrared-thermograph technique to detect udder inflammation in cows. Milchwissenschaft, 55: 607-609.

Berry RJ, Kennedy AD, Scott SL, Kyle BL, Schaefer AL. 2003. Daily variation in the udder surface temperature of dairy cows measured by infrared thermography: Potential for mastitis detection. Canadian Journal of Animal Science, 83(4): 687693.
Bortolami A, Fiore E, Gianesella M, Corro M, Catania S, Morgante M. 2015. Evaluation of the udder health status in subclinical mastitis affected dairy cows through bacteriological culture, somatic cell count and thermographic imaging. Polish Journal of Veterinary Sciences, 18(4): 799-805.

Colak A, Polat B, Okumus Z, Kaya M, Yanmaz LE., Hayirli A. 2008. Early Detection of Mastitis Using Infrared Thermography in Dairy Cows. Journal of Dairy Science, 91(11): 4244-4248.

Ellis KA, Innocent GT, Mihm M, Cripps P, McLean WG, Howard CV, Grove-White D. 2007. Dairy cow cleanliness and milk quality on organic and conventional farms in the UK. Journal of Dairy Research 74:302-310.

Erdem H, Okuyucu I.C. 2019. Influence of hygiene status of cows on somatic cell count and milk components during summer season. Large Animal Review, 25: 7-10.

Golzarian MR, Soltanali H, Doosti Irani O, Ebrahimi S H. 2017. Possibility of early detection of bovine mastitis in dairy cows using thermal images processing. Iranian Journal of Applied Animal Science, 7(4): 549-557.

Hovinen M, Siivonen J, Taponen S, Hänninen L, Pastell M, Aisla AM, Pyörälä S. 2008. Detection of clinical mastitis with the help of a thermal camera. Journal of Dairy Science, 91(12): 4592-4598.

Köster G, Tenhagen BA, Heuwieser W. 2006. Factors associated with high milk test day somatic cell counts in large dairy herds in Brandenburg. I: Housing conditions. Journal of Veterinary Medicine Series A, 53(3): 134-139.

Kul E, Erdem H, Atasever S, 2006. Effect of different udder traits on mastitis and somatic cell count in dairy cows. Journal of Faculty of Agriculture, OMU, 21(3): 350-356.

Poikalainen V, Praks J, Veermäe I, Kokin E. 2012. Infrared temperature patterns of cow's body as an indicator for health control at precision cattle farming. Agronomy Research Biosystem Engineering Special, 10(1): 187-194.

Polat B, Colak A, Cengiz M, Yanmaz LE, Oral H, Bastan A, Kaya S, Hayirli A. 2010. Sensitivity and specificity of infrared thermography in detection of subclinical mastitis in dairy cows. Journal of Dairy Science, 93 (8): 3525-3532.

Porcionato MAF, Canata TF, Deoliviera CL, Dos Santos MV. 2009. Udder thermography of Gyr cows for subclinical mastitis detection. Revista Brasileira de Engenharia de Biossistemas, 3(3): 251-257.

Rainard P, Foucras G, Boichard D, Rupp R. 2018. Invited review: low milk somatic cell count and susceptibility to mastitis. Journal of Dairy Science, 101(8): 6703-6714.

Rekik B, Ajili N, Belhani H, Gara AB, Rouissi H. 2008. Effect of somatic cell count on milk and protein yields and female fertility in Tunisian Holstein dairy cows. Livestock Science, 116(1-3), 309-317.

Sant'Anna AC, Paranhos da Costa MJR. 2011. The relationship between dairy cow hygiene and somatic cell count in milk. Journal of Dairy Science, 94 (8): 3835-3844.

Sathiyabarathi M, Jeyakumar S, Manimaran A, Pushpadass HA, Kumaresan A, Lathwal SS, Sivaram M, Das DN, Ramesha KP, Jayaprakash G. 2018. Infrared thermography to monitor body and udder skin surface temperature differences in relation to subclinical and clinical mastitis condition in Karan Fries (Bos taurus $\times$ Bos indicus) crossbred cows. Indian Journal of Animal Sciences, 88(6): 694-699.

Sathiyabarathi M, Jeyakumar S, Manimaran A, Pushpadass HA, Sivaram M, Ramesha KP, Das, DN, Kataktalware MA, Jayaprakash G, Patbandha TK. 2016. Investigation of body and udder skin surface temperature differentials as an early indicator of mastitis in Holstein Friesian crossbred cows using digital infrared thermography technique. Veterinary World, 9 (12): 1386-1391.

Schreiner DA, Ruegg PL. 2003. Relationship between udder and leg hygiene scores and subclinical mastitis. Journal of Dairy Science, 86(11): 3460-3465. 
Schukken YH, Wilson DJ, Welcome F, Garrison-Tikofsky L, Gonzalez RN. 2003. Monitoring udder health and milk quality using somatic cell counts. Veterinary Research, 34(5): 579-596.

Sharma N, Singh NK, Bhadwal MS. 2011. Relationship of somatic cell count and mastitis: An overview. AsianAustralasian Journal of Animal Sciences, 24(3): 429-438.

Silva RÂBD, Pandorfi H, Almeida GLPD, Montenegro AADA, Silva MVD. 2019. Spatial Dependence of Udder Surface Temperature Variation in Dairy Cows with Healthy Status and Mastitis. Revista Brasileira de Saúde e Produção Animal, $20,1-15$.
Simitzis P, Tzanidakis C, Tzamaloukas O, Sossidou E. 2022. Contribution of Precision Livestock Farming Systems to the Improvement of Welfare Status and Productivity of Dairy Animals. Dairy, 3(1), 12-28.

Yang C, Li G, Zhang X, Gu X. 2018. Udder skin surface temperature variation pre-and post-milking in dairy cows as determined by infrared thermography. Journal of Dairy Research, 85(2): 201-203.

Zaninelli M, Redaelli V, Luzi F, Bronzo V, Mitchell M, Dell'Orto V, Bontempo V, Cattaneo D, Savoini G. 2018. First Evaluation of Infrared Thermography as a Tool for the Monitoring of Udder Health Status in Farms of Dairy Cows. Sensors, 18(3): 862. 